\title{
Development and evaluation of chicken nuggets with partial replacement of meat and fat by pea fibre
}

\author{
Desenvolvimento e avaliação de nuggets de frango com substituição parcial de carne \\ e gordura por fibra de ervilha
}

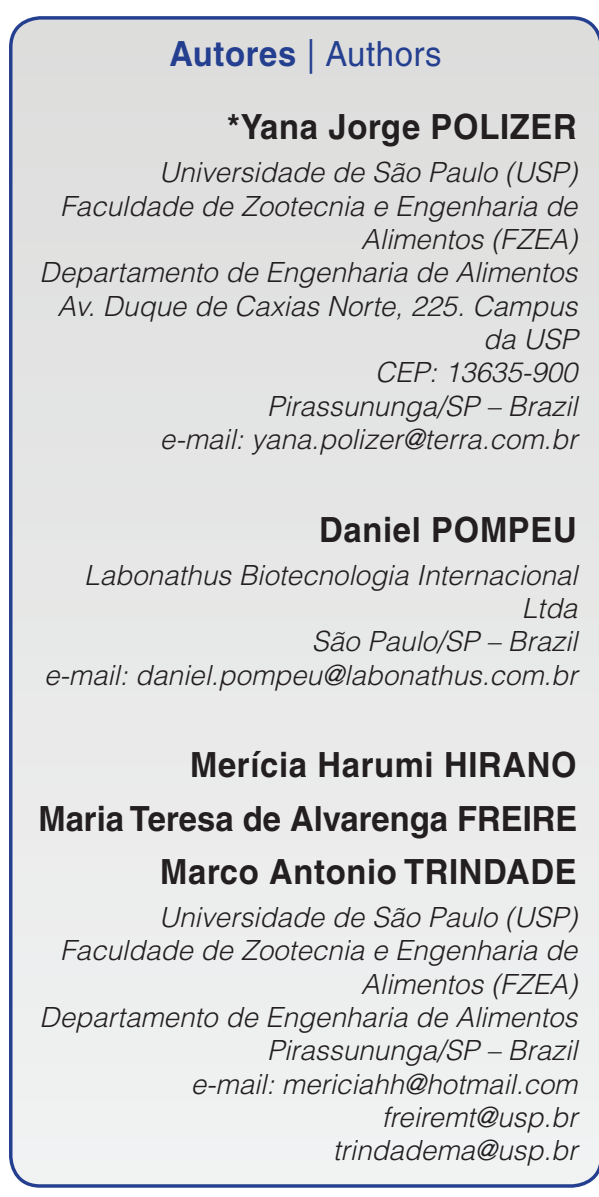

*Autor Correspondente / Corresponding Author

Received: Aug. 21, 2014

Approved: Mar.30, 2015

\section{Summary}

The aim of this study was to develop and evaluate a chicken nugget formulation with partial substitution of the meat or fat by pea fibre. Three formulations were developed: Control (C) - commercial formulation, Fibre Less Meat (FLM) - reduction of $10 \%$ of meat and addition of $2 \%$ of pea fibre and Fibre Less Fat (FLF) - reduction of $10 \%$ of fat and addition of $2 \%$ pea fibre. The products were characterized for their $\mathrm{pH}$ value, instrumental colour, texture, cooking loss (frying), proximate composition, and sensory properties (acceptance test). The control treatment presented lower $(p<0.05) \mathrm{pH}$ values compared to FLM and FLF. The analysis of cooking loss showed no differences ( $p>0.05)$ amongst the treatments. The texture analysis showed no significant differences amongst the treatments for elasticity and cohesiveness, although the FLF batch was firmer than the others $(p<0.05)$. Regarding the sensory acceptance test, the consumers detected no differences ( $p>0.05$ ) amongst the three treatments for aroma, texture, flavour or overall acceptability. One can conclude that it is possible to partially replace meat and fat by pea fibre in chicken nuggets, without compromising most of the physicochemical characteristics and without altering the sensory acceptance.

Key words: Meat product; Sensory acceptance; Texture; Food fibres.

\section{Resumo}

Esse trabalho foi desenvolvido para avaliar nuggets de frango com substituição parcial de carne e gordura por fibra de ervilha. Foram utilizados três tratamentos: Controle (C) - formulação semelhante à comercial; Fibra/ Menos Carne (FMC) - redução de 10\% de carne e adição de 2\% de fibra de ervilha; e Fibra/ Menos Gordura (FMG) - redução de 10\% de gordura e adição de $2 \%$ de fibra de ervilha. Os produtos foram caracterizados quanto ao $\mathrm{pH}$, cor objetiva, perfil de textura, perda de peso após a fritura, composição centesimal e avaliação sensorial (teste de aceitação com escala hedônica de nove pontos). O tratamento Controle apresentou menor valor de $\mathrm{pH}$ em relação aos tratamentos FMC e FMG $(\mathrm{p}<0,05)$. A avaliação da porcentagem de perdas após a fritura não apresentou diferença $(p>0,05)$ entre os tratamentos. Quanto à avaliação de textura, a elasticidade e a coesividade não diferiram $(p>0,05)$ entre os tratamentos, mas o tratamento FMG apresentou maior dureza em relação aos demais $(p<0,05)$. Em relação à avaliação sensorial, os consumidores não detectaram diferenças $(p>0,05)$ entre os três tratamentos para o aroma, a textura, o sabor e a aceitabilidade geral. Pode-se concluir que é possível a utilização de fibra de ervilha, como um substituto parcial de carne e gordura em nuggets de frango, sem prejuízos à maioria das características físico-químicas e sem alterações na aceitação sensorial.

Palavras-chave: Produtos cárneos; Aceitação sensorial; Textura; Fibras alimentares. 
Development and evaluation of chicken nuggets with partial replacement of meat and fat by pea fibre

Polizer, Y. J. et al.

\section{Introduction}

The demand for ready to eat and easily prepared precooked foods is increasing due to the lack of time for food preparation. However, the consumption of such foods has generated health concerns (OLIVEIRA et al., 2013).

The meat industry has been searching for food additives and ingredients for their products that provide nutritional benefits, such as the use of fibres, minerals or bioactive compounds that enable the reduction of the product fat levels (SELGAS et al., 2005).

The use of dietary fibre in meat products comes as an alternative to fat substitution since it does not compromise the texture and increases the water binding capacity, with positive results and cost reductions (SHIMOKOMAKI and OLIVO, 2006). The inclusion of dietary fibres as ingredients in meat products has been considered of interest for the partial replacement of the meat, due to their inherent functional and nutritional effects (HUR et al., 2009; KUMAR et al., 2010).

According to Giuntini et al. (2003), the ideal characteristics for fibres include a high concentration, good proportion between the soluble and insoluble fibres, and soft sensory properties. The positive effects on human health should also be considered, since this aspect is important to consumers. Anti-nutritional compounds should not be present. For industries, availability, affordability and costs are essential and decisive. Several types of fibre have been analysed or combined with other ingredients in the formulation of meat products with reduced fat, such as restructured and emulsified products (WEISS et al., 2010). According to García et al. (2002), the main fibres that can be used in meat products are those extracted from orange, beetroot, wheat, oat and pea.

Scientific data about the addition of pea fibres to chicken nuggets could not be found in the literature, but this fibre can be used to substitute extenders such as soybean protein or starch, commonly applied in meat products formulations. Thus the objective of this study was to develop and evaluate a chicken nugget formulation with partial substitution of the meat or fat by pea fibre.

\section{Material and methods}

\subsection{Experimental design}

Three chicken nugget formulations were developed (Table 1), as follows: 1) Control treatment (C): no fibre inclusion, similar to a commercial formulation, 2) Fibre Less Meat Treatment (FLM): 10\% chicken meat reduction, plus the addition of $2 \%$ pea fibre and $8 \%$ water, developed as the cheapest formulation and 3) Fibre Less Fat treatment (FLF): 10\% reduction of the fat source (chicken skin), plus the addition of $2 \%$ pea fibre addition and $8 \%$ water, developed as the healthiest formulation. All the experiments were repeated twice.
Table 1. Chicken nugget formulations

\begin{tabular}{|c|c|c|c|}
\hline Ingredients & $\begin{array}{c}\mathbf{C}^{1} \\
\%(\mathbf{m} / \mathbf{m})\end{array}$ & $\begin{array}{c}\text { FLM }^{2} \\
\%(m / m)\end{array}$ & $\begin{array}{c}\text { FLF }^{3} \\
\%(m / m)\end{array}$ \\
\hline Chicken breast steak & 70 & 60 & 70 \\
\hline Chicken skin & 20 & 20 & 10 \\
\hline Pea fiber & - & 2 & 2 \\
\hline Water & 4.65 & 12.65 & 12.65 \\
\hline Refined salt & 1.50 & 1.50 & 1.50 \\
\hline White pepper & 0.05 & 0.05 & 0.05 \\
\hline Garlic in paste & 0.30 & 0.30 & 0.30 \\
\hline Fresh onion & 3 & 3 & 3 \\
\hline $\begin{array}{l}\text { Sodium } \\
\text { Tripolyphosphate }\end{array}$ & 0.25 & 0.25 & 0.25 \\
\hline Antioxidant & 0.25 & 0.25 & 0.25 \\
\hline
\end{tabular}

\subsection{Chicken nugget processing}

The raw product of animal origin used in the current study (chicken breast fillet and skin) was purchased from the local markets in Pirassununga - SP, Brazil. The pea fibre (Pea Fibre $150 \mathrm{M}^{\circledR}$ - Roquette Freres, France) used was provided by Labonathus Biotecnologia Internacional Ltda. The pre-dust, adhesion batter and bread crumbs were provided by Kerry do Brasil Ltda. (Rio Claro, SP, Brazil).

According to the producer (Roquette Freres, France), the pea fibre used in the current study presented the following composition: moisture around 10\%, fibre content (dry basis) of 50\%, protein content (dry basis) of $10 \%$ (maximum) and starch (dry basis) of 35\%.

The chicken meat and skin were ground in an electric grinder, with an $8 \mathrm{~mm}$ plate for meat and $2 \mathrm{~mm}$ plate for skin. Subsequently, the meat, skin and other ingredients were mixed for 10 minutes until a homogeneous mixture was obtained. The mixture was separated and moulded into approximately $25 \mathrm{~g}$ portions and then breaded using the following three step procedure: first they were pre-dusted, then batter-coated and finally breaded. The breaded chicken nuggets were pre-fried in vegetable fat at $180^{\circ} \mathrm{C}$ for approximately 4 minutes, until an internal temperature of $72^{\circ} \mathrm{C}$ was reached. After pre-frying, the products were packed, frozen and stored at $-18^{\circ} \mathrm{C}$.

\subsection{Physicochemical characteristics}

\subsubsection{Proximate composition}

The AOAC Official Methods of Analysis (AOAC, 2007) were used to determine the moisture content (950.46), fixed mineral residue or ash content (920.153) and protein content (928.08). The lipid content was determined by the Bligh and Dyer (1959) method. The percentage of total carbohydrates was calculated by difference. 
Development and evaluation of chicken nuggets with partial replacement of meat and fat by pea fibre

Polizer, Y. J. et al.

\subsubsection{Differential Scanning Calorimetry (DSC)}

A model DSC-TA2010 differential scanning calorimeter with a TA5000 controller (TA Instruments) was used, operating with a $\mathrm{N}_{2}$ flow of $45 \mathrm{ml} \mathrm{min}^{-1}$, and heating at $10^{\circ} \mathrm{C} / \mathrm{min}$ from 0 to $100^{\circ} \mathrm{C}$ (FURUKAWA et al., 2004). The sample of approximately $10 \mathrm{mg}$, was placed in a small TA aluminium recipient, hermetically closed, and measured $( \pm 0.01 \mathrm{mg})$ using a precision scale (Ohaus, Analytical Plus). The device was calibrated with Indium $\left(T=156.6^{\circ} \mathrm{C}\right.$ and $\mathrm{DH}=28.71 \mathrm{~J} / \mathrm{g})$.

\subsection{3 pH analysis}

The $\mathrm{pH}$ values were determined using a portable pH meter (HANNA Model HI 99163) with perforation electrodes. The equipment was calibrated using buffer solutions with $\mathrm{pH}$ values of 4.1 and 7.1 and the electrode was cleaned with distilled water between each sample analysis and after the readings. The samples were defrosted in a conventional refrigerator before reading, and each sample read in triplicate with a 3 point perforation.

\subsubsection{Instrumental colour analysis}

The samples were submitted to an objective colour analysis using a portable colorimeter (HunterLab Model MiniScan XE) using the $L^{*}, a^{*}$ and $b^{*}$ scales of the CIELab evaluation system - "Commission Internationale de L'éclairage" with the illuminant D65, observation angle of $10^{\circ}$ and $30 \mathrm{~mm}$ cell opening. Before the analyses, the nuggets were defrosted in a conventional refrigerator and cut in half so that the readings were only taken of the meat mass. The analysis was carried out in triplicate, taking 3 measurements of each sample.

\subsubsection{Cooking loss}

Three samples of each breaded formulation were weighed before and after the frying process as previously described. The percentage of weight loss was calculated according to the Equation 1:

$\%$ Cooking loss $=($ Initial Mass - Final Mass $) \times 100 /$ Initial mass $(1)$

\subsubsection{Texture Profile Analysis (TPA)}

The Texture Profile Analysis (TPA) was carried out using a texturometer (TA-XT2i, Stable Micro Systems, Godalming, UK) previously calibrated with a standard weight of $2 \mathrm{~kg}$. The nugget coatings were removed for the analysis, and the samples cut into cubes $(2 \times 2 \times 1 \mathrm{~cm})$ aiming at only analysing the meat fraction. The samples were then compressed to up to $50 \%$ of the sample thickness, using an aluminium probe (SMS P/20) with speed of $0.3 \mathrm{~mm} / \mathrm{s}$ and time between two compressions of $1.0 \mathrm{~s}$. The texture analyses were carried out with ten samples (per treatment) and the parameters analysed included firmness $(\mathrm{g})$, elasticity $(\mathrm{mm})$, cohesiveness (dimensionless) and chewiness (g.mm).

\subsection{Sensory analysis}

An affective acceptance test was carried out with 60 habitual consumers of chicken nuggets, using a 9-point hedonic scale varying from 9 = "Like Extremely" to 1 = "Dislike Extremely". The parameters analysed were aroma, texture, flavour and overall acceptance. The frozen samples were first heated in an electric oven at $180^{\circ} \mathrm{C}$ for 12 minutes and heating then continued at about $60^{\circ} \mathrm{C}$ for up to 20 minutes for the analysis. If not consumed during this time, the samples were discarded and a new batch prepared for the sensory test. The study was approved by the Ethics Committee of the Faculty of Animal Science and Food Engineering, USP, protocol number: 122.191 (CAAE: 08408612.6.0000.5422)

\subsection{Statistical analysis}

The results were subjected to an analysis of variance (ANOVA) and Tukey's test for the means comparisons, used the SAS version 9.1.3 program (SAS/ STAT, 2005), considering a significance level of $5 \%$.

\section{Results and discussion}

\subsection{Determination of the proximate composition}

According to Table 2, the formulation FLF presented a higher $(p<0.05)$ moisture content $(51.69 \%)$ when compared to formulations C (47.40\%) and FLM (49.08\%). As expected, this difference was due to the substitution of the chicken skin, which contains a lot of fat, by $2 \%$ of fibre and $8 \%$ of water. Regarding the ash content, no significant differences were found amongst the treatments. Santhi and Kalaikannan (2014) analysed nuggets with reduced fat content (25\%) and the addition of wheat flour (10 to $20 \%$ ), and found moisture contents varying between 57.40 and $61.12 \%$, higher moisture

Table 2. Proximate composition of Chicken Nugget formulations (mean \pm standard error).

\begin{tabular}{|c|c|c|c|}
\hline & $\mathbf{C}^{1}$ & FLM $^{2}$ & FLF $^{3}$ \\
\hline Moisture (\%) & $47.40 \pm 0.002^{b}$ & $49.08 \pm 0.011^{b}$ & $51.69 \pm 0.026^{a}$ \\
\hline Ash (\%) & $2.07 \pm 0.014^{a}$ & $2.04 \pm 0.031^{a}$ & $2.01 \pm 0.002^{a}$ \\
\hline Lipids (\%) & $14.32 \pm 0.004^{a}$ & $12.70 \pm 0.003^{b}$ & 10. \\
\hline Proteins (\%) & $17.41 \pm 0.003^{a}$ & $14.33 \pm 0.005^{c}$ & $16.41 \pm 0.081^{b}$ \\
\hline $\begin{array}{l}\text { Carbohydrates } \\
(\%)\end{array}$ & $19.16 \pm 0.009^{b}$ & $21.84 \pm 0.033^{a}$ & $\pm 0.047^{b}$ \\
\hline \multicolumn{4}{|c|}{$\begin{array}{l}\mathrm{C}^{1} \text { (control): similar to a commercial formulation; FLM }{ }^{2} \text { (Fibre/less meat): } \\
10 \% \text { meat reduction, addition of } 2 \% \text { pea fibre and } 8 \% \text { water; FLF } \\
\text { (Fibre/less fat): } 10 \% \text { fat reduction, addition of } 2 \% \text { pear fibre and } 8 \% \\
\text { water. Different lower-case letters in the same row indicate significant } \\
\text { differences }(p<0.05 \text { ) amongst the treatments. }\end{array}$} \\
\hline
\end{tabular}


Development and evaluation of chicken nuggets with partial replacement of meat and fat by pea fibre

Polizer, Y. J. et al.

values being found for the treatments with the addition of wheat flour. Regarding the ash level, the same authors found no differences amongst the treatments.

Table 2 shows that formulation $\mathrm{C}$ had the highest lipid content $(14.32 \%)(p<0.05)$, lower values being found in formulations FLM and FLF $(12.70 \%$ and $10.66 \%$, respectively). These results are due to the $10 \%$ reduction in meat (intramuscular fat) in the formulation FLM and $10 \%$ reduction in chicken skin (fat source) in treatment FLF. Since the lipid content was reduced by $25.55 \%$ in the treatment FLF when compared to $\mathrm{C}$ (similar to that of a commercial formulation), it can be considered to be a light (less fat) product according to Ordinance No 29 of $13^{\text {th }}$ January 1998 of the Ministry of Health (BRASIL, 1998), which establishes a minimum reduction of $25 \%$ of fat (or other components) for a product to be considered as "light".

As shown in Table 2, the differences in protein content found amongst the three treatments were also due to variations in the formulations, the lowest level being found in formulation FLM (14.33\%), due to the $10 \%$ meat content reduction, while treatment FLF (16.41\%) showed an intermediate level. Verma et al. (2010) analysed the proximate composition of nuggets with partial substitution of the meat ( 8.46 to $12.45 \%$ ) by apple pulp (8 to $12 \%$ ), and also reported a variation in the protein content from 17.68 to $14.32 \%$.

Finally, Table 2 shows that formulation FLM had the highest carbohydrate content $(21.84 \%)(p<0.05)$ as compared to formulations C (19.16\%) and FLF (19.81\%). This variation was due to the starch content of the added pea fibre. However, it may also be due to the reduced water retention in the FLM formulation due to the reduction in the meat content. According to the Technical Regulation for the Identity and Quality Standards of Breaded products (BRASIL, 2001), breaded meat products should contain a maximum of $30 \%$ of carbohydrates and a minimum of $10 \%$ of proteins. Thus, all the formulations analysed conformed to the requirements of current Brazilian legislation.

\subsection{Differential Scanning Calorimetry (DSC)}

The DSC analysis of the pea fibre (Figure 1) showed an endothermic peak (Tp) at $65.57^{\circ} \mathrm{C}$, detected between $57.63^{\circ} \mathrm{C}\left(\mathrm{To}-\right.$ onset temperature) and $81.5^{\circ} \mathrm{C}(\mathrm{Tf}-$ end of transition). This thermal transition involved heat or enthalpy $(\Delta \mathrm{H})$ of $0.8758 \mathrm{~J}^{-\mathrm{g}^{-1}}$ and probably represented the starch gelatinization process, starch being a component of the pea fibre (approximately 35\%), confirming that it was in its native state when added to the meat fraction. Similar results were reported by Hoover et al. (2003), who found gelatinization temperatures from $56^{\circ} \mathrm{C}$ to $74^{\circ} \mathrm{C}$ and values for enthalpy from 12.4 to $14.6 \mathrm{J.g}^{-1}$ for different oat cultivars, and also by Bobbio and Bobbio (2003) who found a temperature interval for the gelatinization of cassava starch from $58^{\circ} \mathrm{C}$ to $70^{\circ} \mathrm{C}$. The pea fibre starch might have gelatinized during the pre-frying process, thus contributing to water retention and consequently to similar cooking losses for all the treatments, even those with reduced meat contents.

\section{$3.3 \mathrm{pH}$ analysis}

The control treatment showed a lower $(p<0.05)$ $\mathrm{pH}$ value when compared to treatments FLM and FLF (Table 3). The presence of pea fibre in formulations FLM and FLF may have caused the increase in the $\mathrm{pH}$ values, since the $\mathrm{pH}$ of pea fibre is 7.16. Verma et al. (2010), found $\mathrm{pH}$ values varying between 5.73 and 5.98 when

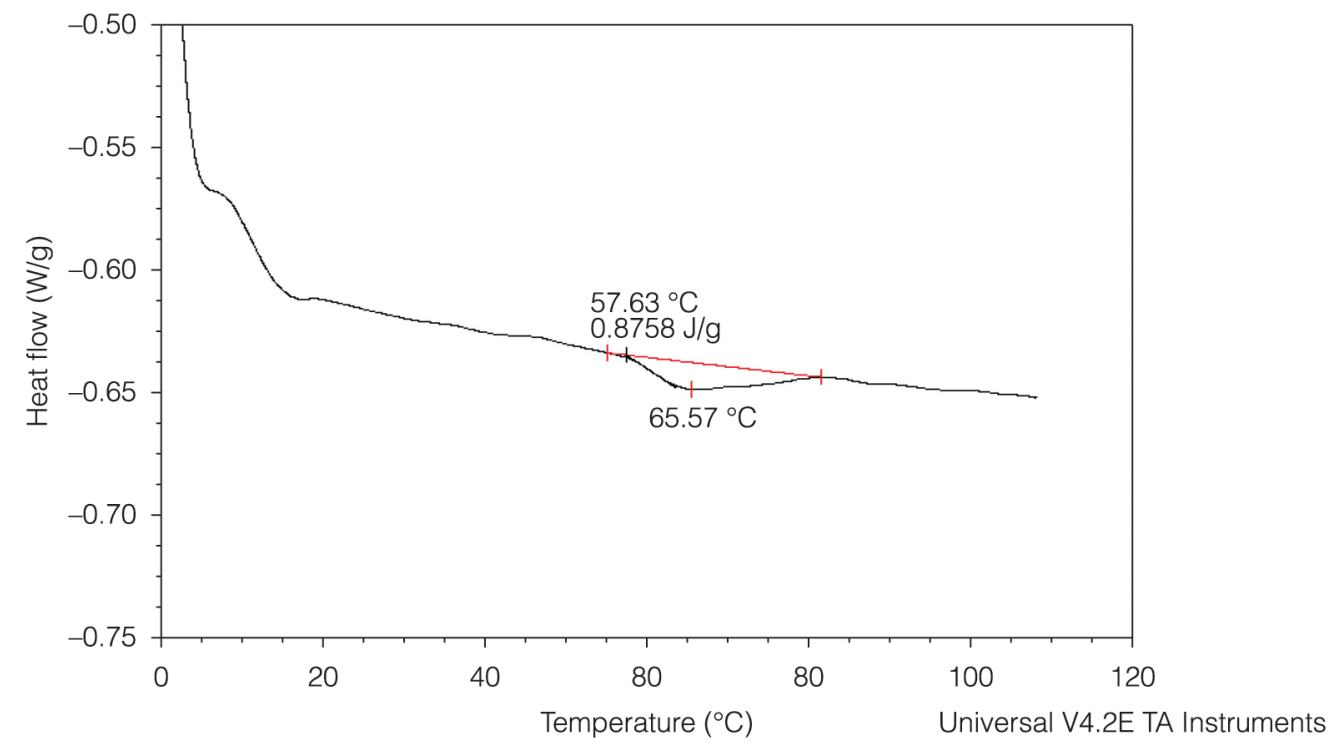

Figure 1. Curve obtained for the pea fibre by differential scanning calorimetry. 


\section{Development and evaluation of chicken nuggets with partial replacement of meat and fat by pea fibre}

Polizer, Y. J. et al.

evaluating chicken nuggets with reduced meat content (8.46 to $12.45 \%$ ) and the addition of apple pulp (8 to 12\%), levels similar to those found in the products with added fibre in the current study. According to the authors, the $\mathrm{pH}$ values of the products decreased with increasing amounts of apple pulp. Kumar et al. (2010) reported controversial results when analysing the $\mathrm{pH}$ values of chicken nuggets produced with banana flour and soybean skin (1 to 5\%), where no significant differences were found amongst the treatments.

\subsection{Instrumental colour analysis}

Lightness $L^{*}$ and yellowness $b^{*}$ did not differ ( $p>0.05$ ) amongst the treatments indicating that the changes in the formulations did not affect these parameters (Table 3 ). Regarding redness $\left(a^{*}\right)$, the formulation FLF differed $(p<0.05 \%)$ from the control $C$ and from the FLM formulation, this variation possibly being due to the reduced fat content. The range of variation was small $(-0.75$ to -1.09$)$ and would probably not change consumer acceptance concerning product appearance. Wan Rosli et al. (2011) evaluated the partial replacement of meat in chicken nuggets by hiratake mushrooms (Pleurotus sajor-caju), otherwise known as oyster mushrooms, at levels of $13.5 \%$ and $27 \%$. The authors found higher values for $L^{*}$ and $b^{*}$ in the control samples, while no differences were noticed for redness $a^{*}$. Verma et al. (2010) reported that the addition of larger amounts of apple pulp to chicken nuggets significantly increased the levels of the parameters for redness $\left(a^{*}\right)$ and yellowness $\left(b^{*}\right)$ of the product.

Amongst other factors, the colour of the food is influenced by the type and concentration of the pigments (LINDAHL et al., 2001) besides the type and quantity of the fibres (FERNÁNDEZ-GINÉS et al., 2005). In the current study the white colour of the pea fibre and the amount used $(2 \% \mathrm{w} / \mathrm{w})$ did not interfere in the final colour of the product.

Table 3. Physicochemical parameters (mean \pm standard error) of nuggets formulated with or without pea fibre.

\begin{tabular}{cccc} 
PARAMETERS & $\mathbf{C}^{\mathbf{1}}$ & FLM $^{2}$ & FLF $^{3}$ \\
$\mathrm{pH}$ & $5.48 \pm 0.03^{\mathrm{b}}$ & $5.72 \pm 0.05^{\mathrm{a}}$ & $5.81 \pm 0.03^{\mathrm{a}}$ \\
$\mathrm{L}^{*}$ & $69.90 \pm 0.23^{\mathrm{a}}$ & $69.51 \pm 0.07^{\mathrm{a}}$ & $69.68 \pm 0.30^{\mathrm{a}}$ \\
$\mathrm{a}^{*}$ & $(-) 1.09 \pm 0.02^{\mathrm{b}}$ & $(-) 1.05 \pm 0.01^{\mathrm{b}}$ & $(-) 0.75 \pm 0.06^{\mathrm{a}}$ \\
$\mathrm{b}^{*}$ & $9.25 \pm 0.15^{\mathrm{a}}$ & $9.15 \pm 0.02^{\mathrm{a}}$ & $9.55 \pm 0.16^{\mathrm{a}}$ \\
$\begin{array}{c}\text { Cooking loss } \\
(\%)\end{array}$ & $4.10 \pm 0.06^{\mathrm{a}}$ & $4.33 \pm 0.13^{\mathrm{a}}$ & $4.20 \pm 0.01^{\mathrm{a}}$ \\
\hline
\end{tabular}

$\mathrm{C}^{1}$ (Control): similar to a commercial formulation; FLM ${ }^{2}$ (Fibre less meat): $10 \%$ meat reduction, addition of $2 \%$ pea fibre and $8 \%$ water; FLF $^{3}$ (Fibre less fat): $10 \%$ fat reduction, addition of $2 \%$ pea fibre and $8 \%$ water. Different lower case letters in the same row indicate significant differences $(p<0.05)$ amongst the treatments.

\subsection{Cooking loss}

The cooking loss (Table 3) was not affected by the treatments. This result is considered favourable, since the pea fibre was capable of incorporating a larger amount of water, as can be seen in the FLM ( $8 \%$ water addition) and FLF (8\% water addition) treatments, maintaining a balanced formulation. Similar results were reported by Wan Rosli et al. (2011) who found no significant differences when analysing the results of cooking loss in nuggets formulated with the partial replacement of meat by hiratake mushrooms (13.5\% and 27\%). Santhi and Kalaikannan (2014) reported that nuggets with reduced fat levels (25\%) and the addition of oat flour (10 - 20\%), reached higher levels of cooking loss $(p<0.05)$ as compared to the control treatment (no addition of oat flour). Kumar et al. (2013) found higher levels of cooking loss for chicken nuggets formulated with banana flour and soybean skin (1 to 5\%) as compared to the control treatment.

According to Olivo (2006), the non-meat ingredients are attracted by the meat proteins, forming a protein net that stabilizes the product. The cooking process also influences the matrix structure formed in the restructured product. Sites that enable the flow of water or denaturing will cause lower shrinkage levels and greater water retention (CHOI et al., 2012; YILDIZ-TURP and SERDAROGLU, 2010; ULU, 2006). The addition of food fibres may decrease weight loss during cooking, due to their great ability to bind water and maintain fat in the matrix. Also the starch present in the pea fibre (35\%) may have contributed to an increase in the water retention capacity since Differential Scanning Calorimetry (DSC) showed that the starch was in its native form. According to García-García and Totosaus (2008), after gelatinization, starch fills the interstitial spaces in the food matrix, interacting with the protein network and increasing the water retention capacity which causes a reduction in weight loss during the cooking step.

\subsection{Texture Profile Analysis (TPA)}

The texture profile analysis showed that elasticity and cohesiveness did not differ ( $p>0.05$ ) amongst the treatments (Table 4). However, the FLF formulation resulted in a firmer product $(p<0.05)$ as compared with the others. Regarding chewiness, FLF presented higher levels $(p<0.05)$ as compared to the FLM formulation, but showed no differences ( $p>0.05)$ as compared to the Control treatment. It is be possible that the greater firmness of the FLF treatment (1686.32 g) was a result of the $10 \%$ fat reduction in the formulation. Wong and Maga (1995) reported greater levels of tenderness in hamburgers with $12 \%$ and $20 \%$ fat levels as compared to $4 \%$, demonstrating the positive effect of fat on product tenderness, confirming the results of the present study. 
Development and evaluation of chicken nuggets with partial replacement of meat and fat by pea fibre

Polizer, Y. J. et al.

Table 4. Texture analysis (mean \pm standard error) of chicken nuggets formulated with or without pea fibre.

\begin{tabular}{lccc} 
PARAMETERS & $\mathbf{C}^{1}$ & FLM $^{2}$ & FLF $^{3}$ \\
\hline Firmness $(\mathrm{g})$ & $1217 \pm 71^{\mathrm{b}}$ & $1274 \pm 19^{\mathrm{b}}$ & $1686 \pm 56^{\mathrm{a}}$ \\
Elasticity (mm) & $0.66 \pm 0.03^{\mathrm{a}}$ & $0.69 \pm 0.01^{\mathrm{a}}$ & $0.64 \pm 0.01^{\mathrm{a}}$ \\
Cohesiveness & $0.68 \pm 0.03^{\mathrm{a}}$ & $0.68 \pm 0.02^{\mathrm{a}}$ & $0.65 \pm 0.01^{\mathrm{a}}$ \\
Chewiness & $597 \pm 17^{\mathrm{ba}}$ & $573 \pm 14^{\mathrm{b}}$ & $685 \pm 13^{\mathrm{a}}$ \\
(g.mm) & & & \\
\hline
\end{tabular}

$\mathrm{C}^{1}$ (Control): similar to a commercial formulation; $\mathrm{FLM}^{2}$ (Fibre less meat): $10 \%$ meat reduction, addition of $2 \%$ pea fibre and $8 \%$ water $\mathrm{FLF}^{3}$ (Fibre less fat): $10 \%$ fat reduction, addition of $2 \%$ pea fibre and $8 \%$ water. Different lower case letters in the same row indicate significant differences $(p<0.05)$ amongst the treatments.

Wan Rosli et al. (2011) found different results in their study involving the addition of hiratake mushroom (Pleurotus sajor-caju) (13.5\% and $27 \%$ ) to replace chicken in nuggets. The authors reported that the firmness, cohesiveness and chewiness of the chicken nuggets decreased proportionally according to the level of mushroom added to the nugget formulations. When analysing chicken nuggets formulated with soybean skin flour (3 to 5\%), Kumar et al. (2013) reported that greater firmness, chewiness and elasticity were related to the products with soybean skin; but no difference was found for cohesiveness.

The differences reported for the instrumentally measured texture parameters may have been related to the type and level of fibre added. Both firm and tender products were obtained when different fibre sources were added to several meat products (FERNÁNDEZ-GINÉS et al., 2003; GARCÍA et al., 2007; THEBAUDIN et al., 1997).

\subsection{Sensory analysis}

According to Table 5, no differences were observed ( $p>0.05)$ amongst the treatments for aroma, texture, flavour and overall acceptability, indicating that the partial replacement of meat $(10 \%)$ or fat $(10 \%)$ by pea fibre (2\%) and water did not change product acceptance by consumers. It is important to point out that all the parameters analysed obtained scores from 7.20 to 7.48 , which represent a classification of "like it" and "like it very much" according to the hedonic scale.

Despite the fact that higher instrumental values for firmness and chewiness (Table 4) were observed for the FLF treatment when compared to the control formulation, no significant differences were observed in the subjective evaluation of the samples during the sensory analysis. The three formulations presented acceptance indexes higher than $70 \%$, which, according to Dutcosky (2007), may be well accepted on the the consumer market.
Table 5. Sensory parameters analysed for the different chicken nugget formulation (average \pm standard error).

\begin{tabular}{lccc} 
PARAMETERS & C $^{1}$ & FLM $^{2}$ & FLF $^{3}$ \\
Aroma & $7.45 \pm 0.15^{\mathrm{a}}$ & $7.38 \pm 0.16^{\mathrm{a}}$ & $7,20 \pm 0.18^{\mathrm{a}}$ \\
Texture & $7.42 \pm 0.14^{\mathrm{a}}$ & $7.38 \pm 0.16^{\mathrm{a}}$ & $7.28 \pm 0.17^{\mathrm{a}}$ \\
Flavour & $7.47 \pm 0.14^{\mathrm{a}}$ & $7.40 \pm 0.15^{\mathrm{a}}$ & $7.47 \pm 0.17^{\mathrm{a}}$ \\
Overall & $7.48 \pm 0.13^{\mathrm{a}}$ & $7.42 \pm 0.15^{\mathrm{a}}$ & $7.38 \pm 0.15^{\mathrm{a}}$ \\
acceptability & & & \\
\hline
\end{tabular}

$\mathrm{C}^{1}$ (Control): similar to the commercial formulation; $\mathrm{FLM}^{2}$ (Fibre less meat): $10 \%$ meat reduction, addition of $2 \%$ pea fibre and $8 \%$ water; FLF $^{3}$ (Fibre less fat): $10 \%$ fat reduction, addition of $2 \%$ pea fibre and $8 \%$ FLF ${ }^{3}$ (Fibre less fat): $10 \%$ fat reduction, addition of $2 \%$ pea fibre and $8 \%$
water. Different lower case letters in the same row indicate significant differences $(p<0.05)$ amongst the treatments.

Similar results were published by Pietrasik et al. (2010), comparing bologna with high fat levels (22\%) and bologna with low fat levels (10\%) and the inclusion of $4 \%$ pea fibre. These authors found no significant differences ( $p>0.05)$ in sensory acceptance amongst the treatments when considering the attributes of appearance, colour, flavour, texture and overall acceptability. Kumar et al. (2013), when carrying out a sensory analysis of chicken nuggets with the partial replacement of meat by soybean skin flour (3 to $5 \%$ ), found no differences in texture, appearance, succulence or overall acceptability in the formulations with the addition of up to $4 \%$ of soybean skin flour.

On the other hand, Verma et al. (2010) found lower values for flavour, texture and overall acceptability when apple pulp (at levels of 8 to $12 \%$ ) was used to partially replace the meat fraction (8.46 to $12.45 \%$ ) in chicken nuggets. Finally, Santhi and Kalaikannan (2014) also found lower scores for succulence, texture and flavour in chicken nuggets with reduced fat content (25\%) and the addition of oat flour (10 to $20 \%$ ). The differences observed in the above studies may be related to the type of substitution (meat or fat) and the quantity or type of fibre added to the formulations.

\section{Conclusion}

Based on the conditions used in the current study, one can conclude that it is possible to partially replace meat (aiming at cost reductions) and fat (leading to a healthier product) by pea fibre (plus water) in chicken nuggets, since it does not compromise most of the physicochemical characteristics and has no impact on consumer acceptance.

\section{Acknowledgements}

The authors would like to thank CAPES for the scholarship and LABONATHUS BIOTECNOLOGIA INTERNACIONAL Ltda Company (São Paulo, Brazil) for the donation of the pea fibre. 
Development and evaluation of chicken nuggets with partial replacement of meat and fat by pea fibre

Polizer, Y. J. et al.

\section{References}

BLIGH, E. G.; DYER, W. J. A rapid method of total lipid extraction and purification. Canadian Journal of Biochemistry and Physiology, Ottawa, v. 37, n. 8, p. 911-917, 1959. http://dx.doi. org/10.1139/059-099. PMid:13671378

BOBBIO, F. O.; BOBBIO, P. A. Carboidratos. In: BOBBIO, F. O.; $\mathrm{BOBBIO}, \mathrm{P} . \mathrm{A}$. (Ed.). Polissacarídeos. Introdução à química de alimentos. 3th. ed. São Paulo: Varela, 2003. cap. 4, p. 55-80.

BRASIL. Ministério da Agricultura Pecuária e Abastecimento. Instrução normativa n. ${ }^{\circ}$ 6, de 15 de fevereiro de 2001. Aprova os regulamentos técnicos de identidade e qualidade de paleta cozida, produtos cárneos salgados, empanados, presunto tipo serrano e prato elaborado pronto ou semipronto contendo produtos de origem animal. Diário Oficial da União, Brasília, DF, 19 fev. 2001. Disponível em: http://extranet. agricultura.gov.br/sislegis-consulta/consultarLegislacao. do?operacao=visualizar\&id=2198 Acesso em: 15 mai. 2014 .

BRASIL. Ministério da Saúde. Agência Nacional de Vigilância Sanitária - ANVISA. Portaria ${ }^{\circ}{ }^{\circ}$ 29, de 13 de janeiro de 1998. Regulamento técnico para fixação de identidade e qualidade de alimentos para fins especiais. Diário Oficial da União, Brasília, DF, 30 mar. 1998. Disponível em: <http://portal.anvisa.gov.br/ wps/wcm/connect/2a1d950047458eca97dbd73fbc4c6735/ PORTARIA_29_1998.pdf?MOD=AJPERES>. Acesso em: 20 mai. 2014.

CHOI, Y. M.; CHOE, J. H.; CHO, D. K.; KIM, B. C. Practical use of surimi-like material made from porcine longissimus dorsi muscle for the production of low-fat pork patties. Meat Science, Barking, v. 90, n. 2, p. 292-296, 2012. http://dx.doi.org/10.1016/j. meatsci.2011.07.013. PMid:21843917

DUTCOSKY, S. D. Análise sensorial de alimentos. 2nd. ed. Curitiba: Champagnat, 2007. 239 p.

FERNÁNDEZ-GINÉS, J. M.; FERNÁNDEZ-LÓPEZ, J.; SAYASBARBERÁ, E.; PÉREZ-ÁLVAREZ, J. A. Meat products as functional foods: a review. Journal of Food Science, Chicago, v. 70, n. 2, p. R37-R43, 2005. http://dx.doi.org/10.1111/j.1365-2621.2005. tb07110.x.

FERNÁNDEZ-GINÉS, J. M.; FERNÁNDEZ-LÓPEZ, J.; SAYAS-BARBERÁ, E.; SENDRRA, E.; PÉREZ-ALVAREZ, J. A. Effects of storage conditions on quality characteristics of bologna sausages made with citrus fibre. Journal of Food Science, Chicago, v. 68, n. 2, p. 710-714, 2003. http://dx.doi. org/10.1111/j.1365-2621.2003.tb05737.x.

FURUKAWA, V. A.; SOBRAL, P. J. A.; HABITANTE, A. M. Q. B.; GOMES, J. D. F. Análise térmica da carne de coelhos. Ciência e Tecnologia de Alimentos, Campinas, v. 24, n. 2, p. 265-269, 2004. http://dx.doi.org/10.1590/S0101-20612004000200018.

GARCÍA, M. L.; CÁCERES, E.; SELGAS, M. D. Utilisation of fruit fibres in conventional and reduced-fat cooked-meat sausages.
Journal of the Science of Food and Agriculture, London, v. 87, n. 4, p. 624-631, 2007. http://dx.doi.org/10.1002/jsfa.2753.

GARCÍA, M. L.; DOMINGUEZ, R.; GALVEZ, M. D.; CASAS, C.; SELGAS, M. D. Utilization of cereal and fruit fibres in low fat dry fermented sausages. Meat Science, Barking, V. 60, n. 3, p. 227-236, 2002. http://dx.doi.org/10.1016/S03091740(01)00125-5. PMid:22063393

GARCÍA-GARCÍA, E.; TOTOSAUS, A. Low-fat sodium-reduced sausages: effect of the interaction between locust bean gum, potato starch and j-carrageenan by a mixture design approach. Meat Science, Asmterdam, v. 78, p. 406-413, 2008.

GIUNTINI, E. B.; LAJOLO, F. M.; MENEZES, E. W. Potencial de fibra alimentar em países ibero-americanos: alimentos, produtos e resíduos. Archivos Latinoamericanos de Nutrición, Caracas, v. 53, n. 1, p. 14-20, 2003. PMid:12942866.

HOOVER, R.; SMITH, C.; ZHOU, Y.; RATNAYAKE, R. M. W. $S$. Physicochemical properties of Canadian oat starches. Carbohydrate Polymers, Barking, v. 52, n. 3, p. 253-261, 2003. http://dx.doi.org/10.1016/S0144-8617(02)00271-0.

HUR, S. J.; LIM, B. O.; PARK, G. B.; JOO, S. T. Effect of various fiber additions on lipid digestion during in vitro digestion of beef patties. Journal of Food Science, Chicago, v. 74, n. 9, p. C653-C657, 2009. http://dx.doi.org/10.1111/j.17503841.2009.01344.x. PMid:20492097

KUMAR, V.; BISWAS, A. K.; CHATLI, M. K.; SAHOO, J. Effect of banana and soybean hull flours on vacuum packaged chicken nuggets during refrigeration storage. International Journal of Food Science \& Technology, Oxford, v. 46, n. 1, p. 122-129, 2010. http://dx.doi.org/10.1111/j.1365-2621.2010.02461.x.

KUMAR, V.; BISWAS, A. K.; SAHOO, J.; CHATLI, M. K.; SIVAKUMAR, S. Quality and storability of chicken nuggets formulated with green banana and soybean hulls flours. Journal of Food Science and Technology, Mysore, v. 50, n. 6, p. 1058-1068, 2013. http://dx.doi.org/10.1007/s13197-011-0442-9. PMid:24426017

LINDAHL, G.; LUNDSTRÖM, K.; TORNBERG, E. Contribution of pigment content, myoglobin forms and internal reflectance to the colour of pork loin and ham from pure breed pigs. Meat Science, Barking, v. 59, n. 2, p. 141-151, 2001. http://dx. doi. org/10.1016/S0309-1740(01)00064-X. PMid:22062672

OLIVEIRA, D. F.; COELHO, A. R.; BURGARDT, V. C. F.; HASHIMOTO, E. H.; LUNKES, A. M.; MARCHI, J. F.; TONIAL, I. B. Alternativas para um produto cárneo mais saudável: uma revisão. Brazilian Journal of Food and Technology, Campinas, v. 16, n. 3, p. 163-174, 2013.

OLIVO, R. A carne e os benefícios da fibra alimentar. In: Olivo, R. (Ed.). Tecnologia da extensão cárnea: atualidades em ciência e tecnologia de carnes. São Paulo: Varela, 2006. cap 12, p. 175-184. 
Development and evaluation of chicken nuggets with partial replacement of meat and fat by pea fibre

Polizer, Y. J. et al.

PIETRASIK, Z.; JANZ, J. A. M. Utilization of pea flour, starchrich and fiber-rich fractions in low fat bologna. Food Research International, Barking, v. 43, n. 2, p. 602-608, 2010.

SANTHI, D.; KALAIKANNAN, A. The effect of the addition of oat flour in low-fat chicken nuggets. Journal of Nutrition \& Food Sciences, New York, v. 4, n. 1, art. 206, 2014.

SAS/STAT ${ }^{\circledR}$ - Statistical Analysis System. Users'Guide. versão 9.1. North Carolina: SAS Institute Inc., 2005.

SELGAS, M. D.; CÁCERES, E.; GARCÍA, M. L. Long-chain soluble dietary fiber as functional ingredient in cooked meat sausages. Food Science \& Technology International, London, v. 11, n. 1, p. 41-47, 2005. http://dx.doi.org/10.1177/1082013205051273.

SHIMOKOMAKI, M.; OLIVO, R. Emulsões cárneas. In: Shimokomaki, M.; Olivo, R. (Ed.). Atualidades em ciência e tecnologia de carnes. São Paulo: Varella, 2006. cap. 12, p. 123-133.

THEBAUDIN, J. Y.; LEFEBVRE, A. C.; HARRINGTON, M.; BOURGEOIS, C. M. Dietary fibers: nutritional and technological interest. Trends in Food Science \& Technology, Cambridge, v. 8, n. 2, p. 41-48, 1997. http://dx.doi.org/10.1016/S09242244(97)01007-8.

ULU, H. Effects of carrageenan and guar gum on the cooking and textural properties of low fat meatballs. Food Chemistry,
London, v. 95, n. 4, p. 600-605, 2006. http://dx.doi.org/10.1016/j. foodchem.2005.01.039.

VERMA, A. K.; SHARMA, B. D.; BANERJEE, R. Effect of sodium chloride replacement and apple pulp inclusion on the physicochemical, textural and sensory properties of low fat chicken nuggets. LWT - Food Science and Technology, London, v. 43, n. 4, p. 715-719, 2010.

WAN ROSLI, W. I.; SOLIHAH, M. A.; AISHAH, M.; NIK FAKURUDIN, N. A.; MOSHIN, S. S. J. Colour, textural properties, cooking characteristics and fibre content of chicken patty added with oyster mushroom (Pleurotus sajor-caju). International Food Research Journal, Serdang, v. 18, p. 621-627, 2011.

WEISS, J.; GIBIS, M.; SCHUH, V.; SALMINEN, H. Advances in ingredient and processing systems for meat and meat products. Meat Science, Barking, v. 86, n. 1, p. 196-213, 2010. http:// dx.doi.org/10.1016/j.meatsci.2010.05.008. PMid:20619800

WONG, N. H.; MAGA, J. A. The effect of fat content on the quality of ground beef patties. Developments in Food Science, Amsterdam, v. 37, p. 1345-1351, 1995. http://dx.doi.org/10.1016/ S0167-4501(06)80237-2.

YILDIZ-TURP, G.; SERDAROGLU, M. Effects of using plum puree on some properties of low fat beef patties. Meat Science, Barking, v. 86, n. 4, p. 896-900, 2010. http://dx.doi.org/10.1016/j. meatsci.2010.07.009. PMid:20732751 